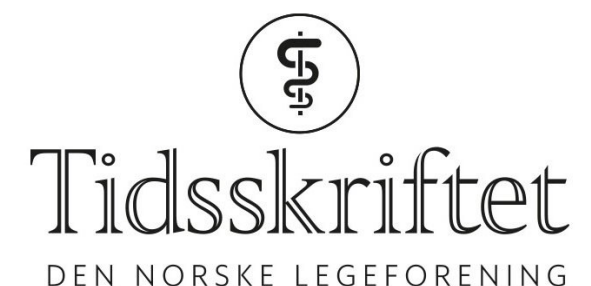

DEN NORSKE LEGEFORENING

\title{
B. Zeller svarer
}

KOMMENTAR

\section{BERNWARD ZELLER}

E-post: bzeller@ous-hf.no

Bernward Zeller er overlege ved Oslo universitetssykehus.

Ingen oppgitte interessekonflikter.

Jeg takker forfatterne for viktige kommentarer til mitt debattinnlegg, hvor jeg etterspurte bedre nasjonale systemer for at alvorlige feil ikke skal gjenta seg.

Det er vanskelig å være uenig med forfatternes konklusjoner. Forebygging av slike feil må være en felles nasjonal anstrengelse hvor alle systemer tas i bruk. Jeg mener allikevel at det finnes helt konkrete forbedringsmuligheter. Haukeland-saken bør føre til en revurdering av Helsetilsynets retningslinjer for varselhåndtering og stedlig tilsyn.

Helsetilsynet leverte en meget grundig og faglig velbegrunnet rapport etter den aktuelle saken. Det er heller ingen tvil om at man har fulgt egne retningslinjer meget nøye.

Problemet er at retningslinjene etter min mening ikke er gode nok. Helsetilsynets «Veileder for varselhåndtering og stedlig tilsyn» (1) sier på 56 sider ingenting om hva som bør skje dersom det avdekkes forhold som kan være av betydning for pasientsikkerheten i resten av Norge (det vil si andre avdelinger enn den som er gjenstand for tilsynet). Helsetilsynets utrykningsgruppe har noen ganger blitt sammenlignet med flyhavarikommisjonen. Kan man tenke seg at flyhavarikommisjonen finner en alvorlig systemfeil ved en flyplass i Norge, og ikke umiddelbart forsikrer seg om at samme feilen ikke finnes ved andre flyplasser? Eller at de finner en alvorlig teknisk feil ved en flytype og ikke umiddelbart setter alle flyene av samme type på bakken inntil det er avklart at disse ikke rammes av samme feilen?

Helsetilsynet bør utvide sine retningslinjer med en klar handlingsplan for tilfeller der det i en sak oppdages alvorlige systemfeil som kan tenkes å forekomme i andre helseforetak. Man bør i så fall forsikre seg om at aktuelle avdelinger umiddelbart får beskjed, og at ev. nødvendige forbedringstiltak innledes med det samme. I den aktuelle saken var Helsetilsynet fra starten av kjent med at Haukeland ikke var det eneste helseforetaket hvor det ikke var etablert trygge rutiner.

\section{LITTERATUR:}

1. Helsetilsynet. Veileder for varselhåndtering og stedlig tilsyn. Tilsynsmessig håndtering av varsler etter alvorlige hendelser, jf. spesialisthelsetjenesteloven § 3-3a.

https://www.helsetilsynet.no/upload/Publikasjoner/internserien/veileder_varselhaandtering_og_ste dlig_tilsyn_Internserien4_2016.pdf(6.3.2018). 
Publisert: 17. april 2018. Tidsskr Nor Legeforen. DOI:10.4045/tidsskr.18.0234 (C) Tidsskrift for Den norske legeforening 2020. Lastet ned fra tidsskriftet.no 